\title{
Adenylylsulphate Reductase in a Dissimilatory Sulphate-reducing Archaebacterium
}

\author{
By NORBERT SPEICH AND HANS G. TRÜPER* \\ Institut für Mikrobiologie der Rheinischen Friedrich-Wilhelms-Universität, \\ Meckenheimer Allee 168, D-5300 Bonn 1, FRG
}

(Received 16 November 1987; revised 17 January 1988)

\begin{abstract}
The recently described extremely thermophilic sulphate-reducing archaebacterium ' $\mathrm{VC}-16$ ' has been shown to contain adenylylsulphate reductase (EC 1.8.99.2). The enzyme was purified 26fold by ammonium sulphate fractionation, DEAE-cellulose chromatography, hydrophobic chromatography and preparative isoelectric focusing. The enzyme preparation gave a single band on analysis by SDS-PAGE. The $M_{\mathrm{r}}$ was 160000 and the enzyme contained 1 mol FAD, $8 \mathrm{mols}$ non-haem iron and $6 \mathrm{mols}$ labile sulphide per mol enzyme. Ferricyanide was used as electron acceptor. The optimal reaction temperature was $85^{\circ} \mathrm{C}$ under the assay conditions used and the pH optimum of the enzyme reaction was 8.0. The $K_{\mathrm{m}}$ values for AMP and ferricyanide were $1 \mathrm{mM}$ and $0.4 \mathrm{mM}$, respectively. The $\mathrm{pI}$ of the archaebacterial adenylylsulphate reductase was 4.8 .
\end{abstract}

\section{INTRODUCTION}

The ability to use sulphate as an external electron acceptor is a common feature of dissimilatory sulphate-reducing bacteria. Until recently, all sulphate-reducing bacteria were assumed to belong to the eubacteria (Fowler et al., 1986); however, an archaebacterial member of this physiological group was isolated and described by Stetter et al. (1987). This new organism, strain 'VC-16' (tentatively called 'Archaeoglobus fulgidus'), is an extreme thermophile and grows at temperatures between 64 and $92^{\circ} \mathrm{C}$, with an optimum at $83^{\circ} \mathrm{C}$. Phylogenetically, strain VC16 belongs in all probability to a new branch positioned between the methanogens and the sulphur-dependent, extremely thermophilic archaebacteria (Stetter et al., 1987; AchenbachRichter et al., 1987).

For dissimilatory sulphate reduction a common mechanism was proposed by Peck (1962). It involves the enzymes 'ATP sulphurylase' (sulphate adenylyltransferase, EC 2.7.7.4), adenylylsulphate (APS) reductase (EC 1.8.99.2) and bisulphite reductase (sulphite reductase, EC 1.8.99.1). We have obtained experimental evidence for the existence of these three enzymes in strain VC-16. APS reductase was studied first because of its key position in dissimilatory sulphate reduction. In this report we show the purification and partial characterization of the first APS reductase of archaebacterial origin.

\section{METHODS}

Organisms and growth conditions. Packed deep-frozen cells of strain VC-16 were received from $\mathrm{K}$. $\mathrm{O}$. Stetter. The growth medium contained $\left(1^{-1}\right) 0.34 \mathrm{~g} \mathrm{KCl}, 2.75 \mathrm{~g} \mathrm{MgCl}_{2} .2 \mathrm{H}_{2} \mathrm{O}, 3.45 \mathrm{~g} \mathrm{MgSO}_{4} .7 \mathrm{H}_{2} \mathrm{O}, 0.25 \mathrm{~g} \mathrm{NH}_{4} \mathrm{Cl}, 0.14 \mathrm{~g}$ $\mathrm{CaCl}_{2} .2 \mathrm{H}_{2} \mathrm{O}, 0 \cdot 14 \mathrm{~g} \mathrm{~K}_{2} \mathrm{HPO}_{4}, 18 \mathrm{~g} \mathrm{NaCl}, 5 \mathrm{~g} \mathrm{NaHCO}_{3}, 2 \mathrm{mg} \mathrm{Fe}\left(\mathrm{NH}_{4}\right)_{2}\left(\mathrm{SO}_{4}\right)_{2} .7 \mathrm{H}_{2} \mathrm{O}, 2 \mathrm{mg} \mathrm{Ni}\left(\mathrm{NH}_{4}\right)_{2}\left(\mathrm{SO}_{4}\right)_{2}$, $1 \mathrm{mg}$ Resazurin, $10 \mathrm{ml}$ trace mineral solution (Balch et al., 1979), 0.5 g yeast extract (Difco), $1 \mathrm{~g} \mathrm{~L}(+)$ lactate and $0.5 \mathrm{~g} \mathrm{Na}_{2} \mathrm{~S}$. The $\mathrm{pH}$ was adjusted with $\mathrm{H}_{2} \mathrm{SO}_{4}$ to 6.9. The bacteria were grown anaerobically in batch cultures in 3001 enamel-protected fermenters (HTE Bioengineering) at $85^{\circ} \mathrm{C}$.

Abbreviation: APS, adenylylsulphate 
Enzyme assay. APS reductase activity was assayed as described by Trüper \& Rogers (1971), with some modifications. The reaction mixture contained $50 \mathrm{mM}$-Tris/ $\mathrm{HCl}, \mathrm{pH} 8 \cdot 0,5 \mathrm{mM}-\mathrm{K}_{3} \mathrm{Fe}(\mathrm{CN})_{6}, 10 \mathrm{mM}$-EDTA, $2 \mathrm{mM}$ AMP and $30 \mathrm{mM}-\mathrm{Na}_{2} \mathrm{SO}_{3}$. The sulphite solution was always freshly prepared in $50 \mathrm{~mm}$-Tris/ $\mathrm{HCl}, \mathrm{pH} 8.0$, containing $5 \mathrm{~mm}$-EDTA. The test volume was $1 \mathrm{ml}$. Absorbance was measured in $1 \mathrm{~cm}$ glass cells at $420 \mathrm{~nm}$.

Enzyme purification. All procedures were done at $4{ }^{\circ} \mathrm{C}$. Packed cells were taken up in about twice their volume of $50 \mathrm{~mm}$-Tris/ $\mathrm{HCl}$ buffer, $\mathrm{pH} 8 \cdot 0$, and disrupted by ultrasonic treatment. The broken cell mass was then centrifuged at $17000 \mathrm{~g}$ for $20 \mathrm{~min}$ to remove the larger fragments. By subsequent centrifugation of the supernatant at $140000 \mathrm{~g}$ for $2 \mathrm{~h}$ a clear supernatant and a pellet consisting of smaller membrane fragments were obtained.

Ammonium sulphate was added to the supernatant to $50 \%$ saturation. The precipitated protein was separated from the supernatant by centrifugation $(17000 \mathrm{~g}, 20 \mathrm{~min})$ and discarded. The supernatant was applied to a column of Phenyl-Sepharose CL-4B $(1.5 \times 20 \mathrm{~cm})$ equilibrated with $50 \mathrm{mM}$-Tris/ $\mathbf{H C l}$, pH 8.0, containing ammonium sulphate at $50 \%$ saturation. The enzyme was eluted with a linear gradient of ammonium sulphate between $50 \%$ and $0 \%$ saturation. The active enzyme fractions were pooled and desalted by a Sephadex G- 25 column. The eluate was applied to a column of DEAE-cellulose $(5 \times 10 \mathrm{~cm})$ equilibrated with $50 \mathrm{mM}$-Tris $/ \mathrm{HCl}, \mathrm{pH} 8.0$ and eluted with a gradient of $0-300 \mathrm{~mm}-\mathrm{NaCl}$ in the same buffer. Active APS reductase fractions were pooled and concentrated by ultrafiltration using an Amicon PM 30 filter. The concentrated protein solution was desalted by a Pharmacia PD10 column and subjected to preparative isoelectric focusing as described by Winter et al. (1975), with minor modification, in an LKB Multiphor 2117. Ultrodex (LKB) (4 g) was mixed with $95 \mathrm{ml} \mathrm{H}_{2} \mathrm{O}$ and $5 \mathrm{ml} \mathrm{Servalyt}$ (pH 4-6) and then poured onto a tray. The gel slurry was evaporated to $65 \%$ of its initial weight. A sample (4 ml) was applied to the gel with an applicator. The cathode and the anode electrode strips were soaked in $1 \mathrm{M}-\mathrm{NaOH}$ and in $1 \mathrm{M}-\mathrm{H}_{3} \mathrm{PO}_{4}$, respectively. The isoelectric focusing was run at $4{ }^{\circ} \mathrm{C}$ at $1500 \mathrm{~V}$ and $20 \mathrm{~mA}$ for $16 \mathrm{~h}$. The focused protein in the gel was visualized by placing a dry filter paper on top of the gel; small amounts of protein were absorbed by the paper and afterwards stained with Coomassie brilliant blue R-250. The part of the gel containing APS reductase was applied to a small column $(1.5 \times 6 \mathrm{~cm})$ and the protein was eluted with $50 \mathrm{mM}-$ Tris/HCl, pH 8.0.

$S D S-P A G E$. This was done according to the method of Weber \& Osborn (1969) in order to determine the subunit composition of the purified enzyme. The gel was run at $\mathrm{pH} 7 \cdot 1$ in a $7.5 \%(\mathrm{w} / \mathrm{v})$ polyacrylamide gel containing $0 \cdot 1 \%(\mathrm{w} / \mathrm{v})$ SDS. A low- $M_{\mathrm{r}}$ calibration kit (14000-94000, Pharmacia) was used for standards. The gel was stained for protein with Coomassie brilliant blue R-250.

$M_{r}$ determination by FPLC. This was done with an analytical FPLC column (Superose 6, Pharmacia) and a flow rate of $24 \mathrm{ml} \mathrm{h}^{-1}$. The column was equilibrated with $50 \mathrm{mM}$-potassium phosphate buffer, $\mathrm{pH} 7 \cdot 5$, containing $0 \cdot 1 \mathrm{M}$ $\mathrm{NaCl}$. The proteins of Boehringer Combithek 2 were used as references.

Analytical procedures. Flavin was identified by chromatography according to Kilgour et al. (1957), with some modifications. The organic phase of the following solvent system was used: $\mathrm{n}$-butanol/acetic acid/water $\left(40: 10: 50\right.$, by vol.). The APS reductase was denatured by heat treatment $\left(15 \mathrm{~min}, 120^{\circ} \mathrm{C}\right)$, chromatographed on Cellulose MN 300 plates (Macherey \& Nagel) and the $R_{F}$ value of the released flavin component was compared with that for FAD and FMN. The flavins were detected by their fluorescence at $254 \mathrm{~nm}$.

The concentration of the flavin was determined by the method of Rao et al. (1967), and non-haem iron by the ferrozine method (Sigma) in $1 \mathrm{~cm}$ cells at $560 \mathrm{~nm}$. Labile sulphide was determined according to King \& Morris (1966). Absorption spectra were determined in a Beckman $M 6$ double beam spectrophotometer using $1 \mathrm{~cm}$ quartz cells. Reduced spectra were obtained by addition of a few crystals of sodium dithionite to the protein solution.

Protein assay. Protein concentration was measured by the method of Bradford (1976) with bovine serum albumin as a standard.

\section{RESULTS}

\section{Purification of the APS reductase}

The supernatant of the $50 \%$ ammonium sulphate precipitation was loaded on a PhenylSepharose CL-4B column for hydrophobic interaction chromatography (Fig. 1). After pooling and desalting the fractions of the active peak, the solution was applied to a DE-52 column. Fractions containing APS reductase were pooled, concentrated and subjected to preparative isoelectric focusing. The purification procedures are summarized in Table 1.

\section{Properties of the APS reductase}

The purified enzyme was analysed by SDS-PAGE. Only one protein band was visible with an apparent $M_{\mathrm{r}}$ of 80000 . The $M_{\mathrm{r}}$ of the native protein, as determined by FPLC, was approximately 160000 . The temperature optimum for activity was $85^{\circ} \mathrm{C}$ under the assay conditions used. Higher temperatures were inhibitory and no activity was found below $55^{\circ} \mathrm{C}$ (Fig. 2). The pH optimum was $8 \cdot 0$. 


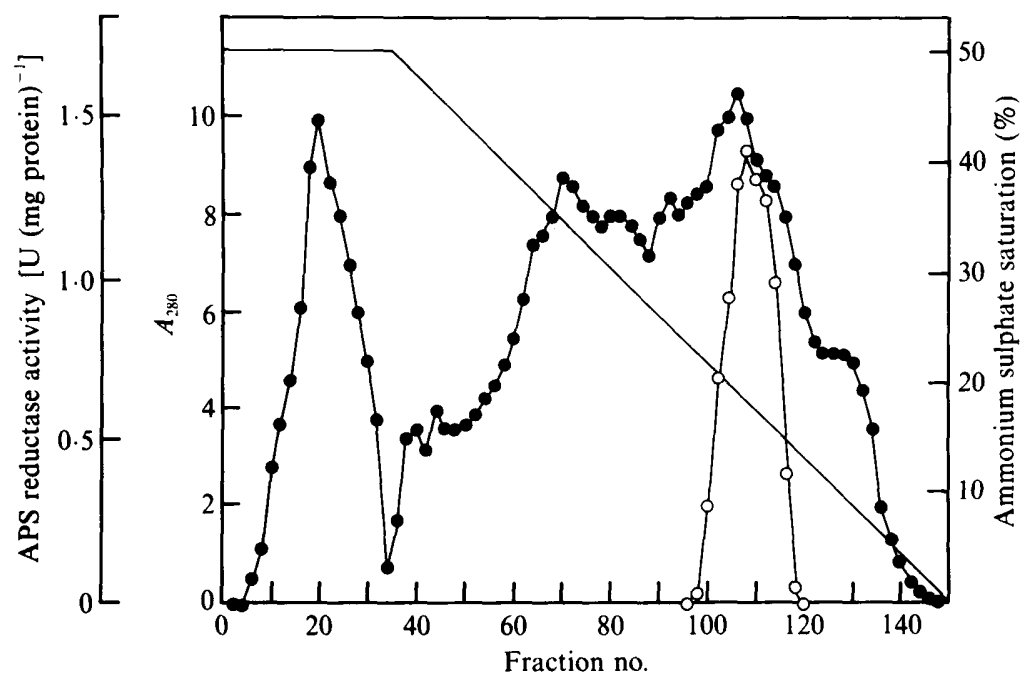

Fig. 1. Elution profile of APS reductase from strain VC-16 on a Phenyl-Sepharose CL-4B column $(1.5 \times 20 \mathrm{~cm})$. Experimental details are given in Methods. The flow rate was $20 \mathrm{ml} \mathrm{h}^{-1}$ and $4 \mathrm{ml}$ fractions were collected. $O$, APS reductase activity; $\odot$, protein monitored by recording the absorbance at $280 \mathrm{~nm}$.

Table 1. Purification of APS reductase from the sulphate-reducing archaebacterium strain VC-16

Activity is expressed in units (U), where $1 \mathrm{U}$ is $1 \mu \mathrm{mol} \mathrm{Fe}(\mathrm{CN}) 6^{3-}$ reduced $\mathrm{min}^{-1}$. IEF, isoelectric focusing.

\begin{tabular}{|c|c|c|c|c|c|c|}
\hline Step & $\begin{array}{c}\text { Volume } \\
\text { (ml) }\end{array}$ & $\begin{array}{c}\text { Total activity } \\
\text { (U) }\end{array}$ & $\begin{array}{c}\text { Total protein } \\
(\mathrm{mg})\end{array}$ & $\begin{array}{l}\text { Specific activity } \\
\left(\mathrm{U} \mathrm{mg}^{-1}\right)\end{array}$ & $\begin{array}{l}\text { Purification } \\
\text { (fold) }\end{array}$ & $\begin{array}{c}\text { Yield } \\
(\%)\end{array}$ \\
\hline Crude extract & 60 & $217 \cdot 5$ & 2364 & 0.092 & 1 & 100 \\
\hline Supernatant $(140000 \mathrm{~g})$ & 53 & 213.5 & $1654 \cdot 8$ & $0 \cdot 129$ & 1.4 & $98 \cdot 2$ \\
\hline Ammonium sulphate & 44 & 159 & $822 \cdot 8$ & $0 \cdot 193$ & $2 \cdot 1$ & $73 \cdot 3$ \\
\hline Phenyl-Sepharose & 52 & 143.7 & 115 & $1 \cdot 25$ & $13 \cdot 6$ & $66 \cdot 2$ \\
\hline DEAE-cellulose & 48 & 134.9 & 71 & 1.9 & $20 \cdot 7$ & $62 \cdot 2$ \\
\hline Preparative IEF & 4 & 82.8 & 34.6 & $2 \cdot 39$ & 26 & $38 \cdot 2$ \\
\hline
\end{tabular}

With the purified enzyme, activities were measured by varying the concentrations of the substrates. The $K_{\mathrm{m}}$ values from respective Lineweaver-Burk plots were $1 \mathrm{mM}$ for AMP and $0.4 \mathrm{~mm}$ for ferricyanide. However, by varying the concentration of sulphite, a sigmoid substrate saturation curve was obtained and thus no $K_{\mathrm{m}}$ value for sulphite could be calculated.

The nucleotide specificity of APS reductase was determined by replacing AMP with other nucleotides (Table 2). DeoxyAMP and GMP replaced AMP with relative efficiency, while the enzyme showed no activity with UMP.

The absorption spectrum of the purified APS reductase is shown in Fig. 3. The maximum at $390 \mathrm{~nm}$ in the oxidized state led us to expect iron-sulphur clusters to be part of the enzyme. The absorption difference in the range from 400 to $500 \mathrm{~nm}$ suggested the presence of flavin groups, according to Rao et al. (1967). For the spectrophotometric characterization of the flavin moiety, the purified enzyme solution $(5 \mathrm{ml})$ was treated with saturated urea for $48 \mathrm{~h}$ at $4{ }^{\circ} \mathrm{C}$. The resulting yellow mixture was applied to a Sephadex G-25 column and eluted with $10 \mathrm{~mm}$ $\mathrm{Tris} / \mathrm{HCl}, \mathrm{pH} 7 \cdot 0$. One yellow band appeared, which showed characteristic properties of flavins. Maxima occurred at 446,364 and $280 \mathrm{~nm}$ and minima at 404 and $325 \mathrm{~nm}$ in the oxidized state. Reduction of the flavin by addition of dithionite resulted in a strong decrease in absorption in the range between 400 and $500 \mathrm{~nm}$. The flavin was identified chromatographically as FAD. The 


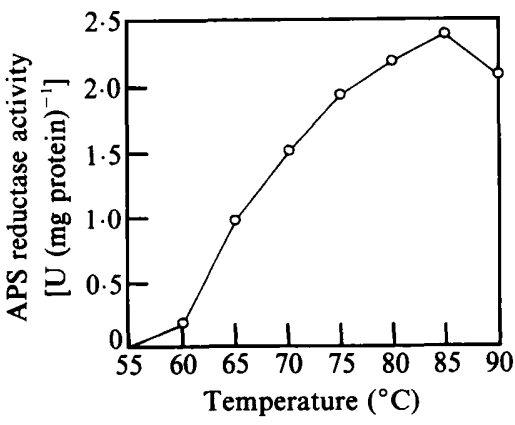

Fig. 2

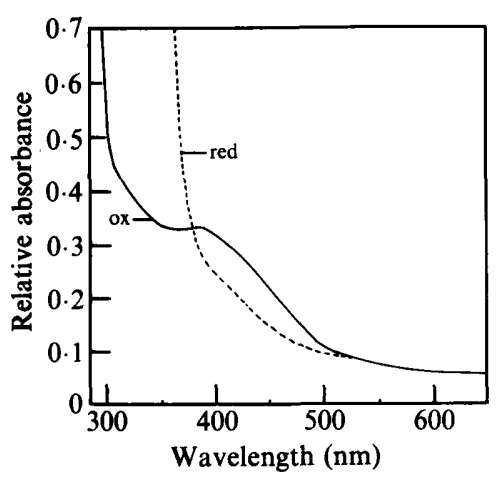

Fig. 3

Fig. 2. Temperature optimum curve for APS reductase activity from sulphate-reducing archaebacterium strain VC-16, under the assay conditions used.

Fig. 3. Absorption spectra of oxidized and reduced APS reductase from sulphate-reducing archaebacterium strain VC-16. The amount of protein was $1.4 \mathrm{mg}$. ox, oxidized; red, reduced.

Table 2. Nucleotide specificity of purified APS reductase

$\begin{array}{lc}\text { Nucleotide } & \begin{array}{c}\text { Activity } \\ (\%)\end{array} \\ \text { AMP } & 100 \\ \text { IMP } & 41 \\ \text { GMP } & 68 \\ \text { CMP } & 24 \\ \text { UMP } & 0 \\ \text { DeoxyAMP } & 74 \\ \text { ADP } & 50 \\ \text { ATP } & 24\end{array}$

amount of FAD per molecule was determined as described by Rao et al. (1967). Non-haem iron and labile sulphide were determined as described above. Each mol of APS reductase from strain VC-16 contained 1 mol FAD, 8 mols non haem iron and 6 mols labile sulphide. The isoelectric point of the enzyme protein (pI) was $4 \cdot 8$, as determined by preparative isoelectric focusing.

\section{DISCUSSION}

APS reductase has a key position in dissimilatory sulphur metabolism. The enzyme has been proven to occur in all dissimilatory sulphate-reducing eubacteria, in some thiobacilli and in most phototrophic sulphur bacteria. So far, it has been purified from Desulfovibrio vulgaris (the strain used by Peck et al., 1965, does not belong to the species $D$. desulfuricans): Thiobacillus denitrificans (Bowen et al., 1966); Thiobacillus thioparus (Lyric \& Suzuki, 1970); Thiocapsa roseopersicina (Trüper \& Rogers, 1971); Chlorobium limicola $f$. thiosulfatophilum (Kirchhoff \& Trüper, 1974); and Desulfobulbus propionicus (Stille \& Trüper, 1984). These eubacterial enzymes are iron-sulphur flavoproteins with $M_{\mathrm{r}}$ values between 170000 and $218500,1 \mathrm{~mol}$ FAD, 4-13 mols non-haem iron and 4-12 mols labile sulphide per mol enzyme protein.

The results of the $M_{\mathrm{r}}$ determination and also the molar ratio of the constituents of the archaebacterial APS reductase reveal strong similarities with the enzymes from eubacteria. Haem groups, as were reported by Trüper \& Rogers (1971) for the enzyme from Thiocapsa roseopersicina, could not be detected.

The APS reductase from strain VC-16 appeared to be a dimer composed of two equal subunits of $M_{\mathrm{r}} \mathbf{8 0 0 0 0}$. It is not or only slightly bound to the membrane. This agrees with the results reported from eubacterial sulphate reducers. In contrast, Trüper \& Peck (1970) found that the enzyme is membrane bound in phototrophic bacteria. 
Table 3. Comparison of the properties of the APS reductases purified so far

$K_{\mathrm{m}}$ values (mM) were determined with ferricyanide as electron acceptor. NG, Not given.

\begin{tabular}{|c|c|c|c|c|c|c|c|}
\hline Property & $\begin{array}{c}\text { Desulfovibrio } \\
\text { vulgaris }^{a}\end{array}$ & $\begin{array}{c}\text { Thiobacillus } \\
\text { denitrificans }^{b}\end{array}$ & $\begin{array}{c}\text { Thiobacillus } \\
\text { thioparus }^{c}\end{array}$ & $\begin{array}{c}\text { Thiocapsa } \\
\text { roseopersicina }\end{array}$ & $\begin{array}{c}\text { Chlorobium } \\
\text { limicola }^{e}\end{array}$ & $\begin{array}{c}\text { Desulfobulbus } \\
\text { propionicus }\end{array}$ & 'VC-16' \\
\hline$M_{\mathrm{r}}$ & $\begin{array}{l}220000 \\
6-8\end{array}$ & NG & $\begin{array}{l}170000 \\
8-10\end{array}$ & 180000 & 210000 & 175000 & 160000 \\
\hline FAD per molecule & 1 & 1 & $e_{1}^{-10}$ & $\begin{array}{l}4 \\
1\end{array}$ & 1.4 & $\begin{array}{l}8 \\
1\end{array}$ & $\begin{array}{l}8 \\
1\end{array}$ \\
\hline Haem per molecule & 0 & 0 & 0 & 2 & 0 & 0 & 0 \\
\hline pH optimum & $7 \cdot 4$ & $7 \cdot 2$ & $7 \cdot 4$ & $8 \cdot 0$ & 8.5 & $7 \cdot 7$ & $8 \cdot 0$ \\
\hline$K_{\mathrm{m}}$ for sulphite & 2 & 1.5 & $2 \cdot 5$ & 1.5 & 0.91 & $1 \cdot 3$ & NG \\
\hline$K_{\mathrm{m}}$ for $\mathrm{AMP}$ & NG & 0.041 & $0 \cdot 1$ & 0.073 & 0.2 & 0.09 & 1 \\
\hline$K_{\mathrm{m}}$ for $\mathrm{Fe}(\mathrm{CN})_{6}^{3-}$ & NG & NG & NG & 0.13 & 0.091 & 0.089 & 0.4 \\
\hline
\end{tabular}

${ }^{a}$ Peck et al., $1965 ;{ }^{b}$ Bowen et al., $1965 ;{ }^{c}$ Lyric \& Suzuki, $1970 ;{ }^{d}$ Trüper \& Rogers, 1971 ; ${ }^{e}$ Kirchhoff \& Trüper, $1974 ;{ }^{f S t i l l e ~ \& ~ T r u ̈ p e r, ~} 1984$. 
An exceptional character of the archaebacterial APS reductase is its extreme thermophily: eubacterial APS reductases are generally described as mesophilic enzymes. The optimal reaction temperature of the archaebacterial enzyme (found to be $85^{\circ} \mathrm{C}$ under the assay conditions used) is very close to the optimal growth temperature of this organism $\left(83^{\circ} \mathrm{C}\right)$. This high temperature did not allow us to use cytochrome $c$ (either from horse heart or from Candida krusei) instead of ferricyanide as electron acceptor in the reaction. The use of these cytochromes has been reported by Lyric \& Suzuki (1970), Trüper \& Rogers (1971), Bramlett \& Peck (1975) and Stille \& Trüper (1984). A second obvious difference with respect to the eubacterial enzymes is the substrate affinity of the strain VC-16 APS reductase. The $K_{\mathrm{m}}$ values for AMP and ferricyanide are significantly higher than those of all eubacterial enzymes, although one would expect that the reactivity of the substrates is increased at high temperatures. An unusual feature as compared with APS reductases so far described is the sigmoid substrate saturation curve obtained by varying the concentration of sulphite. Further kinetic studies are necessary to explain this effect. An allosteric regulation of the enzyme does not seem to be feasible, as the enzyme reaction proceeds in the opposite (i.e. reductive) direction in vivo.

Peck et al. (1965) reported that only purine nucleotides could be used as substrates by the APS reductases. This result was confirmed by Bowen et al. (1966), Trüper \& Rogers (1971) and Stille \& Trüper (1984). The archaebacterial enzyme shows the lowest activities with pyrimidine nucleotides. In contrast, activity with CMP and UMP was shown by Lyric \& Suzuki (1970) in Thiobacillus thioparus. Surprisingly the strain VC-16 enzyme showed high activity with ADP as a substrate. A probable reason for this is the hydrolysis of the nucleotide at the reaction temperature of $85^{\circ} \mathrm{C}$

The existence of ATP sulphurylase, bisulphite reductase (unpublished results) and APS reductase in strain $\mathrm{VC}-16$ leads to the conclusion that the pathway for dissimilatory sulphate reduction is identical with that known from eubacteria. It seems that this pathway was formed very early during evolution. However, another explanation may be lateral gene transfer. Further research at the molecular level such as sequence analysis of the different APS reductases is under way to investigate the evolution of this key enzyme of sulphur metabolism.

This work is dedicated to John R. Postgate at the occasion of his 65th birthday, in recognition of his vast contribution to our knowledge of dissimilatory sulphate reduction.

We thank Karl O. Stetter for kindly supplying us with frozen cell material. This work was partly sponsored by the Verband der Chemischen Industrie.

\section{REFERENCES}

ACHENBACH-Richter, L., STETter, K. O. \& Woese, C. R. (1987). A possible biochemical missing link among archaebacteria. Nature, London 327, 348-349.

Balch, W. E., Fox, G. E., Magrum, L. J., Woese, C. R. \& Wolfe, R. S. (1979). Methanogens: reevaluation of a unique biological group. Microbiological Reviews 43, 260-296.

Bowen, T. J., HAPPOLD, F. C. \& TAYLOR, B. F. (1966). Studies on adenosine- 5 '-phosphosulfate reductase from Thiobacillus denitrificans. Biochimica et biophysica acta 118, 566-576.

BRADFORD, M. M. (1976). A rapid and sensitive method for the quantitation of microgram quantities of protein utilizing the principle of protein-dye binding. Analytical Biochemistry 72, 248-254.

Bramlett, R. N. \& PeCK, H. D., JR (1975). Some physical and kinetic properties of adenylyl sulfate reductase from Desulfovibrio vulgaris. Journal of Biological Chemistry 250, 2979-2986.

Fowler, V. J., Widdel, F., Pfennig, N., Woese, C. R. \& Stackebrandt, E. (1986). Phylogenetic relationships of sulfate- and sulfur-reducing eubacteria. Systematic and Applied Microbiology 8, 3241.
Kilgour, G. L., Felton, S. P. \& Huennekens, F. M. (1957). Paper chromatography of flavins and flavin nucleotides. Journal of the American Chemical Society 79, 2254-2256.

KING, T. E. \& MORRIS, R. O. (1966). Determination of acid-labile sulfide and sulfhydrylgroups. Methods in Enzymology 20, 635-641.

KIRChHOFF, J. \& TrüPER, H. G. (1974). Adenylylsulfate reductase in Chlorobium limicola. Archives of Microbiology 100, 115-120.

LYRIC, R. M. \& SuzUKI, I., (1970). Enzymes involved in the metabolism of thiosulfate by Thiobacillus thioparus. Properties of adenosine-5'-phosphosulfate reductase. Canadian Journal of Biochemistry 48, 344-354.

PECK, H. D., JR (1962). Symposium on metabolism of inorganic compounds. V. Comparative metabolism of inorganic sulfur compounds in microorganisms. Bacteriological Reviews 26, 67-94.

PeCK, H. D., JR, Deacon, T. E. \& Davidson, J. T. (1965). Studies on adenosine-5'-phosphosulfate reductase from Desulfovibrio desulfuricans and Thiobacillus thioparus. I. The assay and purification. Biochimica et biophysica acta 96, 429-446. 
Rao, N. A., Felton, S. P. \& Huennekens, F. M. (1967). Quantitative determination of mitochondrial flavins. Methods in Enzymology 10, 494-499.

Stetter, K. O., LAUERER, G., THOMM, M. \& Neuner, A. (1987). Isolation of extremely thermophilic sulfate reducers: evidence for a novel branch of archaebacteria. Science 236, 822-824.

STILlE, W. \& TRÜPER, H. G. (1984). Adenylylsulfate reductase in some new sulfate-reducing bacteria. Archives of Microbiology 137, 145-150.

TRÜPER, H. G. \& PECK, H. D., JR (1970). Formation of adenylyl sulfate reductase in phototrophic bacteria. Archives of Microbiology 73, 125-142.
TRÜPER, H. G. \& Rogers, L. A. (1971). Purification and properties of adenylyl sulfate reductase from the photosynthetic bacterium Thiocapsa roseopersicina. Journal of Bacteriology 108, 1112-1121.

WEBER, K. \& OSBORN, M. (1969). The reliability of molecular weight determination by dodecyl sulfatepolyacrylamide gel electrophoresis. Journal of Biological Chemistry 244, 4406-4412.

Winter, A., Perlmutter, H. \& Davies, H. (1975). Preparative flat-bed electrofocusing in a granulated gel with the LKB 2117 Multiphor. Application Note No. 198. LKB, Sweden. 